\title{
Growth Patterns in the First Three Years of Life in Children with Classical Congenital Adrenal Hyperplasia Diagnosed by Newborn Screening and Treated with Low Doses of Hydrocortisone
}

\author{
W. Bonfiga, ${ }^{a}$ H. Schmidt ${ }^{a} \quad$ H.P. Schwarz ${ }^{a}$ \\ aPediatric Endocrinology, Dr. von Haunersches Kinderspital, Ludwig Maximilians Universität München, and \\ bPediatric Endocrinology, Department of Pediatrics, Technische Universität München, Munich, Germany
}

\author{
Key Words \\ Congenital adrenal hyperplasia $\cdot$ Newborn screening $\cdot$ \\ Growth $\cdot$ Glucocorticoids
}

\begin{abstract}
Background: Linear growth is the best clinical parameter for monitoring metabolic control in classical congenital adrenal hyperplasia (CAH). Objective: To analyze growth patterns in children with $\mathrm{CAH}$ diagnosed by newborn screening and treated with relatively low doses of hydrocortisone during the first year of life. Patients and Methods: 51 patients (27 females) were diagnosed with classical $\mathrm{CAH}$ by newborn screening. All patients were treated with relatively low doses of hydrocortisone (9-15 $\mathrm{mg} / \mathrm{m}^{2}$ body surface area). $47 \mathrm{pa}$ tients were additionally treated with fludrocortisone. $R \boldsymbol{e}$ sults: At birth, height SDS (H-SDS) was $1.1 \pm 1$ in girls and 0.9 \pm 1.5 in boys. After 3 months, H-SDS decreased to $0.4 \pm 0.9$ in girls and to $0.1 \pm 1.3$ in boys. Over the 3-year period, $\mathrm{H}$ SDS further decreased to $-0.4 \pm 1.8$ in girls and to $-0.8 \pm 1$ in boys and approached the genetic height potential (target H-SDS of girls $-0.5 \pm 0.3$ and target H-SDS of boys $-0.9 \pm$ $0.7)$. During the first 9 months of age, growth velocity was slightly decreased in girls $(18.2 \pm 1.9 \mathrm{~cm})$ and boys $(17.3 \pm$
\end{abstract}

\section{KARGER}

Fax +4161306 1234

E-Mail karger@karger.ch

www.karger.com
(C) 2010 S. Karger AG, Basel

$1663-2818 / 11 / 0751-0032 \$ 38.00 / 0$

Accessible online at:

www.karger.com/hrp
$1.6 \mathrm{~cm}$ ) when compared to a healthy reference population (girls $19.0 \pm 3.9 \mathrm{~cm}$ and boys $18.7 \pm 4.7 \mathrm{~cm}$ ). At the age of 3 years, bone age was appropriate for chronological age in both girls ( $2.7 \pm 0.5$ years) and boys ( $2.9 \pm 0.5$ years). Conclusion: Birth length is above average in children with classical $\mathrm{CAH}$, which might be the result of untreated hyperandrogenism in utero. With relatively low doses of hydrocortisone treatment, growth velocity decreases slightly during the first 9 months and H-SDS then approaches the genetic height potential.

Copyright ๑ 2010 S. Karger AG, Basel

\section{Introduction}

Congenital adrenal hyperplasia $(\mathrm{CAH})$ is caused by the loss or severe decrease in activity in 1 of the 5 steroidogenic enzymes involved in cortisol biosynthesis. In over $90 \%$ of all cases, 21 -hydroxylase deficiency is found [1]. It is caused by mutations in the 21-hydroxylase gene CYP21A2, which is located in the human leukocyte antigen (HLA) gene cluster region on the short arm of chromosome 6 (6p21.3) [2]. The disease is divided on clinical grounds into the classical and the nonclassical forms. 
There are different degrees of severity of the same enzymatic deficiency in these two forms of the disease. The worldwide incidence of classical 21-hydroxylase deficiency is approximately 1 in 14,000 births [3]. Therefore, carrier frequency of this autosomal recessive disease is about 1 in 60. 21-hydroxylase deficiency leads to accumulation of 17-hydroxyprogesterone and results in increased production of adrenal androgens and decreased production of cortisol. In addition to impaired cortisol biosynthesis, aldosterone production may be decreased as well (saltwasting $\mathrm{CAH}$ ). In simple virilizing $\mathrm{CAH}$, there is virilization of external genitalia in newborn females and pseudoprecocious puberty due to overproduction of androgens in both sexes. In salt-wasting $\mathrm{CAH}$, additional severe renal salt loss occurs as a consequence of aldosterone deficiency. Overproduction of androgens causes virilization, accelerated growth, advanced skeletal maturation and early epiphyseal fusion. While the various forms of $\mathrm{CAH}$ differ in their degree of enzymatic deficiency, they all represent a therapeutic challenge to pediatric endocrinologists attempting to optimize growth.

Traditional treatment consists of the suppression of ACTH through glucocorticoid replacement, in attempt to reduce excessive androgen production and its consequences. Low-dose treatment with glucocorticoids may result in androgen excess with advancement of bone age and a reduced final height. In overtreatment, growth is suppressed by the growth inhibiting effects of glucocorticoids. Further side effects of overtreatment are truncal obesity and osteoporosis. Alternate approaches to the treatment of $\mathrm{CAH}$ have been investigated recently, including the use of antiandrogens, aromatase inhibitors and adrenalectomy [4]. However, the mainstay of therapy remains judicious glucocorticoid treatment along with careful monitoring of growth velocity and skeletal maturation, along with urine, serum and salivary steroid hormone levels [5].

Since newborn screening is available nowadays, diagnosis of CAH is no longer delayed. There is some evidence that infants with CAH are relatively androgen-insensitive during the first year of life [6]. Thus, it seems reasonable and ethical to treat infants with $\mathrm{CAH}$ with lower doses of hydrocortisone during that period.

\section{Patients and Methods}

In Bavaria, newborn screening for CAH started on January 1, 1999. Since then, 51 patients ( 27 females, 24 males) diagnosed with classical CAH due to 21-hydroxylase deficiency were referred to our institution. The diagnosis of 21-hydroxylase defi- ciency was confirmed by genotyping in all patients ( 5 patients with homozygous deletion of the whole gene, 15 patients with deletion of one gene and mutation of second gene, 7 patients with conversion of one gene and mutation of second gene, 24 patients with compound heterozygous mutations; table 1). The diagnosis was also reconfirmed by hormonal analysis (low cortisol and elevated 17-hydroxyprogesterone concentration). During the first 6 months of life, all patients were treated with $1 \mathrm{mg}$ of hydrocortisone 3 times daily and $0.05 \mathrm{mg}$ of fludrocortisone 2 or 3 times daily. Thereafter, hydrocortisone doses were individually increased and the fludrocortisone dose was reduced. When plasma renin activity rose $>18 \mathrm{ng} / \mathrm{ml} / \mathrm{h}$ after reduction of fludrocortisone during the first 6 months of life or $>8 \mathrm{ng} / \mathrm{ml} / \mathrm{h}$ after 6 months of life, fludrocortisone was increased and patients were assumed to have the salt-wasting form of $\mathrm{CAH}$. All patients were continuously cared for in our clinic, with follow-up appointments every 3 months during the first 2 years of life, and every 6 months thereafter.

Adjustment of the glucocorticoid dose was made using auxological data (goal: linear growth as best clinical parameter of metabolic control) and hormonal data (treatment goals: morning serum 17-hydroxyprogesterone $<18 \mathrm{nmol} / \mathrm{l}$ and plasma renin activity $<18 \mathrm{ng} / \mathrm{ml} / \mathrm{h}$ until 6 months of age, $<5.5 \mathrm{ng} / \mathrm{ml} / \mathrm{h}$ above the age of 6 months). These cutoffs were determined using age and sexspecific normative data for assays at the own endocrine laboratory. When enough serum was available, androstenedione and testosterone were measured as well, but these parameters were not available for all patients at all times and were therefore excluded from the analysis. Until the age of 2 years, height was measured in a lying position using a pediatric measuring device (infantometer); after 2 years of age, height was measured in a standing position using a digital telescopic wall-mounted stadiometer (Ulmer Stadiometer). Height standard deviation scores (H-SDS) were calculated with a growth calculator, using reference data from Prader et al. [7] which are used in the 'Alpine' region of Europe (Switzerland, Austria, Southern Germany). Height was compared with matched controls among healthy children with the same birth years. Controls were recruited from an outpatient pediatrician. In Germany, children have regular check-ups at their pediatrician and height, weight and head circumference are documented in a little yellow booklet.

Weight was determined to the nearest of $0.1 \mathrm{~kg}$ using an electronic scale (Seca $753 \mathrm{E}$ ). Body mass index (BMI) was calculated as weight $(\mathrm{kg}) /$ height $\left(\mathrm{m}^{2}\right)$ and BMI-SDS was derived from data published by Cole et al. [8].

Bone age was assessed at the age of 3 years by X-ray of the left hand using the Greulich and Pyle method [9]. Bone age was read by both an experienced pediatric endocrinologist and a radiologist, who both agreed on the result of each other's reading after discussing the X-ray.

Most parental heights were asked and available on all patients. Parental heights could not be measured in all parents because both parents were not present in most cases. When asked for, parental heights mostly result in overestimation, especially among fathers, which has to be taken into account. The genetic target height was calculated as midparental height (the mean of the two parents' heights) plus $6.5 \mathrm{~cm}$ for boys and minus $6.5 \mathrm{~cm}$ for girls.

Statistical analyses were performed with the nonparametric Wilcoxon test and for group comparisons with the nonparametric Mann-Whitney U test. 
Table 1. Genotype/phenotype of the study group

\begin{tabular}{|c|c|c|c|}
\hline Patient & Sex & Genotype & Phenotype \\
\hline 1 & M & del del & SW \\
\hline 2 & M & del del & SW \\
\hline 3 & M & del del & SW \\
\hline 4 & M & I2G del & SW \\
\hline 5 & M & I2G R356W & SW \\
\hline 6 & M & I172N I172N & SW \\
\hline 7 & M & I2G I172N & SV \\
\hline 8 & M & $\mathrm{I} 2 \mathrm{G} \mathrm{I} 160 \mathrm{~N}$ & SW \\
\hline 9 & M & $\mathrm{I} 2 \mathrm{G} \mathrm{I} 2 \mathrm{G}$ & SW \\
\hline 10 & M & Q318X Q318X & SW \\
\hline 11 & M & $\mathrm{I} 2 \mathrm{G}$ I2G & SW \\
\hline 12 & M & $\operatorname{del}$ I2G & SW \\
\hline 13 & M & del Q318X & SW \\
\hline 14 & M & $\mathrm{I} 2 \mathrm{G} \mathrm{I} 2 \mathrm{G}$ & SV \\
\hline 15 & M & del I2G & SW \\
\hline 16 & M & I2G del & SW \\
\hline 17 & M & $\mathrm{I} 2 \mathrm{G} ?$ & SW \\
\hline 18 & M & I172N conv & SW \\
\hline 19 & M & I2G I172N & SW \\
\hline 20 & M & I2G del & SW \\
\hline 21 & M & I2G del & SW \\
\hline 22 & M & $\mathrm{I} 2 \mathrm{G} \mathrm{I} 2 \mathrm{G}$ & SW \\
\hline 23 & M & $\mathrm{I} 2 \mathrm{G} \mathrm{I} 2 \mathrm{G}$ & SW \\
\hline 24 & M & $\operatorname{del} I 2 G$ & SW \\
\hline 25 & $\mathrm{~F}$ & $\mathrm{I} 172 \mathrm{~N} \mathrm{I} 2 \mathrm{G}$ & SW \\
\hline 26 & $\mathrm{~F}$ & $\mathrm{I} 2 \mathrm{G} \mathrm{I} \mathrm{I} \mathrm{G}$ & SW \\
\hline 27 & $\mathrm{~F}$ & $\mathrm{I} 2 \mathrm{G} \mathrm{I} 2 \mathrm{G}$ & SW \\
\hline 28 & $\mathrm{~F}$ & I172N conv & SW \\
\hline 29 & $\mathrm{~F}$ & I172N conv & SW \\
\hline 30 & $\mathrm{~F}$ & $\mathrm{I} 2 \mathrm{G}$ conv & SW \\
\hline 31 & $\mathrm{~F}$ & $\mathrm{I} 2 \mathrm{G}$ conv & SW \\
\hline 32 & $\mathrm{~F}$ & I172N I172N & SW \\
\hline 33 & $\mathrm{~F}$ & I172N Q474X & SV \\
\hline 34 & $\mathrm{~F}$ & $\mathrm{I} 2 \mathrm{G} \mathrm{I} 2 \mathrm{G}$ & SW \\
\hline 35 & $\mathrm{~F}$ & I2G del & SW \\
\hline 36 & $\mathrm{~F}$ & I2G del & SW \\
\hline 37 & $\mathrm{~F}$ & $\mathrm{I} 172 \mathrm{~N} \mathrm{I} 2 \mathrm{G}$ & SW \\
\hline 38 & $\mathrm{~F}$ & del I172N & SW \\
\hline 39 & $\mathrm{~F}$ & $\mathrm{I} 2 \mathrm{G} \mathrm{I} 172 \mathrm{~N}$ & SW \\
\hline 40 & $\mathrm{~F}$ & $\operatorname{del} I 2 G$ & SW \\
\hline 41 & $\mathrm{~F}$ & $\mathrm{I} 2 \mathrm{G}$ conv & SW \\
\hline 42 & $\mathrm{~F}$ & $\mathrm{I} 2 \mathrm{G}$ conv & SW \\
\hline 43 & $\mathrm{~F}$ & del del & SW \\
\hline 44 & $\mathrm{~F}$ & del I2G & SW \\
\hline 45 & $\mathrm{~F}$ & $\mathrm{I} 2 \mathrm{G} \mathrm{I} 172 \mathrm{~N}$ & SW \\
\hline 46 & $\mathrm{~F}$ & $\mathrm{I} 2 \mathrm{G} \mathrm{I} 2 \mathrm{G}$ & SW \\
\hline 47 & $\mathrm{~F}$ & I172N R356W & SW \\
\hline 48 & $\mathrm{~F}$ & I2G del & SW \\
\hline 49 & $\mathrm{~F}$ & del W204X & SW \\
\hline 50 & $\mathrm{~F}$ & del del & SW \\
\hline 51 & $\mathrm{~F}$ & R356W I172N & SV \\
\hline
\end{tabular}

del = Deletion; conv = conversion, $\mathrm{I} 2 \mathrm{G}=$ intron 2 splice site mutation; $\mathrm{SW}=$ salt-wasting; $\mathrm{SV}=$ simple virilizing.

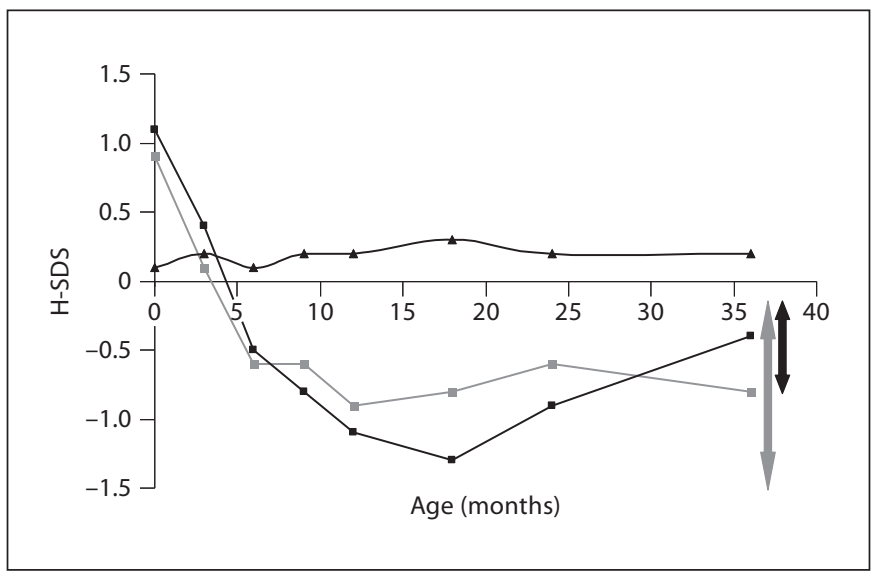

Fig. 1. Growth pattern of CAH patients: course of H-SDS. Black line with boxes: girls. Grey line with boxes: boys. Black line with triangles: reference group. Black arrow: target height girls (mean $\pm 1 \mathrm{SD}$ ); grey arrow: target height boys (mean $\pm 1 \mathrm{SD}$ ).

Statistical analyses were done with the SPSS 10.0 software (2002; SPSS Inc., Chicago, Ill, USA). p $<0.05$ was considered statistically significant.

\section{Results}

The majority of patients were diagnosed with saltwasting $\mathrm{CAH}$ and only 4 patients were classified as simple virilizing $\mathrm{CAH}$. At birth, $\mathrm{H}$-SDS related to gestational age was $1.1 \pm 1$ in girls, and $0.9 \pm 1.5$ in boys, respectively. Accordingly, the birth length of both girls and boys with classical CAH was significantly increased when compared with healthy controls. After 3 months, H-SDS decreased significantly to $0.4 \pm 0.9$ SDS in girls $(\mathrm{p}<0.01)$ and to $0.1 \pm 1.3$ SDS in boys $(\mathrm{p}<0.01)$. At 1 year of age, $\mathrm{H}$-SDS further decreased to $-1.1 \pm 1.8$ SDS in girls and $-0.9 \pm 0.9$ SDS in boys $(\mathrm{p}<0.01)$. After 3 years, H-SDS was $-0.4 \pm 1.8$ SDS in girls and $-0.8 \pm 1$ SDS in boys, and approached the genetic height potential (target $\mathrm{H}$ SDS of girls: $-0.5 \pm 0.3$, target H-SDS of boys: $-0.9 \pm 0.7$; table 2, fig. 1).

During the first 9 months of age, growth velocity was subnormal in girls $(18.2 \pm 1.9 \mathrm{~cm})$ and boys $(17.3 \pm 1.6$ $\mathrm{cm})$ when compared to a healthy reference population (girls: $19.0 \pm 3.9 \mathrm{~cm}$, boys: $18.7 \pm 4.7 \mathrm{~cm}$, Prader et al. [7], $\mathrm{p}<0.05)$. During the second and third year of life, growth velocity was in the normal range (growth velocity second year: CAH girls $11.9 \pm 1.4 \mathrm{~cm}$, CAH boys 12 $\pm 1.7 \mathrm{~cm}$ vs. reference girls $11.1 \pm 2 \mathrm{~cm}$ and reference 
Table 2. Longitudinal data on H-SDS, BMI-SDS, hydrocortisone dose and 17-OH-progesterone (mean $\pm 1 \mathrm{SD}$ )

\begin{tabular}{|c|c|c|c|c|c|c|c|c|c|c|}
\hline & Birth & 3 months & 6 months & 9 months & 12 months & 18 months & 24 months & 36 months & $\begin{array}{l}\text { Target } \\
\text { H-SDS }\end{array}$ & $\begin{array}{l}\text { Bone age at } \\
36 \text { months } \\
\text { years }\end{array}$ \\
\hline \multicolumn{11}{|l|}{ Girls $(\mathrm{n}=27)$} \\
\hline H-SDS & $1.1 \pm 1$ & $0.4 \pm 0.9^{*}$ & $-0.5 \pm 1.2^{*}$ & $-0.8 \pm 1.2^{*}$ & $-1.1 \pm 1.8^{*}$ & $-1.3 \pm 1.4^{*}$ & $-0.9 \pm 1.2^{*}$ & $-0.4 \pm 1.8^{*}$ & $-0.5 \pm 0.3$ & $2.7 \pm 0.5$ \\
\hline BMI-SDS & & $0.1 \pm 1.7$ & $-0.3 \pm 1.4$ & $-0.4 \pm 1.3$ & $-0.3 \pm 1.3$ & $-0.3 \pm 0.7$ & $0.1 \pm 0.8$ & $0 \pm 1$ & & \\
\hline $\mathrm{HC}$ dose, $\mathrm{mg} / \mathrm{m}^{2}$ & & $10.2 \pm 2.3$ & $10.3 \pm 3.8$ & $9.6 \pm 1.6$ & $10.5 \pm 2.2$ & $10.9 \pm 2.6$ & $11.1 \pm 2.1$ & $12.8 \pm 1.9$ & & \\
\hline 17-OH-progesterone, $\mathrm{nmol} / \mathrm{l}$ & & $29.9 \pm 31$ & $10 \pm 11$ & $7.7 \pm 7.5$ & $7.7 \pm 6$ & $6.7 \pm 7.9$ & $20 \pm 36$ & $4.7 \pm 5.5$ & & \\
\hline \multicolumn{11}{|l|}{ Boys $(n=24)$} \\
\hline $\mathrm{H}-\mathrm{SDS}$ & $0.9 \pm 1.5$ & $0.1 \pm 1.3^{*}$ & $-0.6 \pm 1.2^{*}$ & $-0.6 \pm 0.9^{*}$ & $-0.9 \pm 0.9^{*}$ & $-0.8 \pm 1.1^{*}$ & $-0.6 \pm 0.9^{*}$ & $-0.8 \pm 1^{*}$ & $-0.9 \pm 0.7$ & $2.9 \pm 0.5$ \\
\hline BMI-SDS & & $-0.3 \pm 1.6$ & $-0.6 \pm 1.4$ & $-0.7 \pm 1.5$ & $-0.5 \pm 1.5$ & $-0.5 \pm 1.4$ & $-0.5 \pm 1.3$ & $-0.1 \pm 1.1$ & & \\
\hline $\mathrm{HC}$ dose, $\mathrm{mg} / \mathrm{m}^{2}$ & & $10.8 \pm 3.2$ & $10 \pm 3.2$ & $9.3 \pm 2$ & $9.6 \pm 2.3$ & $10.4 \pm 1.9$ & $11.3 \pm 1.7$ & $12.1 \pm 1.6$ & & \\
\hline 17-OH-progesterone, nmol/l & & $78.6 \pm 117$ & $26.3 \pm 39$ & $10.2 \pm 8$ & $12.5 \pm 18$ & $10.6 \pm 6.7$ & $6.4 \pm 8.6$ & $17 \pm 50$ & & \\
\hline
\end{tabular}

H-SDS decreases significantly compared to H-SDS at birth $\left({ }^{*} \mathrm{p}<0.05\right)$ in boys and girls with CAH. HC $=$ Hydrocortisone.

Table 3. Growth velocity at 9 months, 2 and 3 years of age (mean $\pm 1 \mathrm{SD}$ )

\begin{tabular}{llrr}
\hline & & CAH patients & Reference population [7] \\
\hline Growth velocity during first 9 months, cm/year & females & $18.2 \pm 1.9$ & $19.0 \pm 3.9^{*}$ \\
& males & $17.3 \pm 1.6$ & $18.7 \pm 4.7^{*}$ \\
Growth velocity at 2 years, cm/year & females & $11.9 \pm 1.4$ & $11.1 \pm 2.0$ \\
& males & $12.0 \pm 1.7$ & $11.0 \pm 3.5$ \\
Growth velocity at 3 years, cm/year & females & $8.6 \pm 1.4$ & $8.5 \pm 1.5$ \\
& males & $8.1 \pm 2.0$ & $8.3 \pm 1.3$ \\
\hline
\end{tabular}

$\mathrm{CAH}$ patients compared to a healthy reference population $\left({ }^{*} \mathrm{p}<0.05\right)$.

boys $11.0 \pm 3.5 \mathrm{~cm}$; growth velocity third year: CAH girls $8.6 \pm 1.4 \mathrm{~cm}, \mathrm{CAH}$ boys $8.1 \pm 2 \mathrm{~cm}$ vs. reference girls $8.5 \pm 1.5 \mathrm{~cm}$ and reference boys $8.3 \pm 1.3 \mathrm{~cm}$; table 3 ).

With hydrocortisone substitution in the low range of general treatment recommendations [10] (1 mg of hydrocortisone 3 times daily during the first 6 months, corresponding to approximately $10 \mathrm{mg}$ of hydrocortisone per $\mathrm{m}^{2}$ body surface area), in girls the mean plasma 17-hydroxyprogesterone concentration was still elevated at 3 months and subsequently decreased to the treatment goal $<18 \mathrm{nmol} / \mathrm{l}$. With the same treatment regimen in boys, the 17-hydroxyprogesterone concentration was elevated at 3 and at 6 months of age and decreased to a mean concentration of $10.2 \mathrm{nmol} / \mathrm{l}$ at the age of 9 months. Over 3 years, the mean hydrocortisone substitution dose ranged between 9.3 and $12.8 \mathrm{mg}$ per $\mathrm{m}^{2}$ body surface area (table 2). One patient suffered from adrenal crisis in the context of gastroenteritis while failing to increase hydrocortisone dose.

Growth Patterns in Children with CAH
At the age of 3 years, bone age was appropriate for chronological age in both girls ( $2.7 \pm 0.5$ years) and boys ( $2.9 \pm 0.5$ years), indicating that the relatively low dosage of hydrocortisone during the first 6 months did not lead to accelerated bone age.

At 3 months of age, BMI-SDS was $0.1 \pm 1.7$ in girls and $-0.3 \pm 1.6$ in boys. BMI-SDS remained around the mean over the study period (BMI-SDS at 3 years: $0 \pm 1$ SDS in girls vs. $-0.1 \pm 1.1$ SDS in boys; table 1 ).

\section{Discussion}

Since newborn screening is available nowadays, diagnosis of CAH is no longer delayed and optimal treatment strategies during the first months of life have become more important.

According to the consensus statement on 21-hydroxylase deficiency from the Lawson Wilkins Pediatric Endo- 
crine Society and The European Society for Pediatric Endocrinology, typical hydrocortisone doses during infancy range between 10 and $15 \mathrm{mg} / \mathrm{m}^{2}$ body surface area, but higher doses up to $25 \mathrm{mg} / \mathrm{m}^{2}$ body surface area may be necessary initially [10].

From the observation of growth patterns of untreated boys with delayed diagnosis of simple virilizing $\mathrm{CAH}$ in the pre-newborn screening era, it has been hypothesized that infants are relatively insensitive to androgen excess [11]. In another synopsis of 17 untreated patients with simple virilizing $\mathrm{CAH}$, growth velocity was not increased during the first year of life. After that period, a progressive increase in height velocity and bone maturation was observed [6]. Therefore, lower doses of hydrocortisone may be sufficient during the first months of life in terms of growth. For this reason we accepted suboptimal hormonal control of $\mathrm{CAH}$ at the age of 3 months and continued hydrocortisone substitution at the low end of therapeutic recommendations [10]. Even though metabolic control was definitely not too tight, $\mathrm{H}$-SDS decreased significantly during the first 6 months of life, indicating again that infants are not very sensitive to androgens but may be extremely sensitive to glucocorticoid treatment in terms of growth inhibition. Also during the first 9 months of age, growth velocity was decreased when compared to healthy controls, which might have resulted from the growth suppressing effects of glucocorticoid treatment. Therefore, our relatively low hydrocortisone dose might still be too high during the first year of life. On the other hand, with hydrocortisone substitution at the low end of therapeutic recommendations [10], we do not believe that decreased growth velocity was caused by a glucocorticoid deficient state since only 1 patient suffered from adrenal crisis in the context of gastroenteritis while failing to increase hydrocortisone dose. The fact that H-SDS in the target $\mathrm{H}-\mathrm{SDS}$ range is reached between the ages of 1 and 3 years suggests that hydrocortisone substitution was sufficient. Another indicator for adequate hydrocortisone substitution in our patients was the age-appropriate bone age at 3 years. The vast majority of patients in our study were classified as having salt-wasting CAH. This is somewhat unusual and may partially explain lower hydrocortisone requirements because patients were additionally treated with fludrocortisone.

In our cohort, birth length was above average in both boys and girls with classical CAH. Significantly increased birth length was also observed in an Italian and Finnish population with classical CAH $[12,13]$. Among the patients with classical $\mathrm{CAH}$, those with the salt-wasting form were longer but weighed less than those with the simple virilizing form [12]. Worldwide, healthy males are known to be heavier than healthy females at term birth. This difference is at least partially explained by androgen action in utero [14]. Androgens appear to affect the growth of bone cells, acting both directly and indirectly through the IGF-1 system $[15,16]$. Increased expression of IGF-1 and IGF-BP3 mRNA as well as increased IGF-1 and IGF-BP3 concentration were observed after treatment of human osteoblasts with dihydrotestosterone [17]. Interestingly, in our cohort of $\mathrm{CAH}$ infants, the birth length of girls was greater than the birth length of boys.

We found H-SDS to decrease significantly during the first year of life in girls and boys with classical CAH. This result is comparable to that of a multicenter study by Hargitai et al. [18] who observed a decline of the general growth trendline to the 10 th centile by the age of 1.5 years in girls and boys with salt-wasting $\mathrm{CAH}$.

With relatively high doses of hydrocortisone (19.6$28.2 \mathrm{mg} / \mathrm{m}^{2} /$ day) during the first 2 years of life, Manoli et al. [19] found a negative correlation between hydrocortisone dose and height at 2 years $(r=-0.79)$ in patients with salt-wasting CAH diagnosed within the first 2 months of life. Mean height at 2 years was -0.33 SDS in girls and +0.45 SDS in boys. Moreover, height at 2 years showed a positive correlation to final height in this rather timely diagnosed subset of patients.

In a retrospective analysis of the growth inhibiting effects of glucocorticoid treatment in salt-wasting $\mathrm{CAH}$, Stikkelbroeck et al. [20] found that in the interval between 6 and 12 months and between 8 and 14 years of age, there is a dose-dependent negative effect of glucocorticoids on linear growth. Weight and weight for height were not significantly influenced by glucocorticoid dose at any age. The authors conclude that the daily glucocorticoid dose during these intervals has to be adjusted carefully to allow optimal linear growth and adult height.

In summary, we were able to identify a typical growth pattern of patients with classical CAH diagnosed by newborn screening and treated with relatively low doses of hydrocortisone. Suboptimal hormonal control at 3 or 6 months of age does not seem to accelerate bone age and growth due to relative androgen insensitivity of infants at that age. With hydrocortisone substitution between 9 and $15 \mathrm{mg}$ per $\mathrm{m}^{2}$ body surface area per day, patients were able to achieve H-SDS in the target height range. 


\section{References}

1 Speiser PW, White PC: Congenital adrenal hyperplasia. N Engl J Med 2003;349:776788.

2 Hughes IA: Congenital adrenal hyperplasia - a continuum of disorders. Lancet 1998; 352:752-754.

3 Cutler GB, Laue L: Congenital adrenal hyperplasia due to 21-hydroxylase deficiency. N Engl J Med 1990;323:1806-1813.

4 Laue L, Merke DP, Jones JV, Barnes KM, Hill S, Cutler GB: A preliminary study of flutamide, testolactone, and reduced hydrocortisone dose in the treatment of congenital adrenal hyperplasia. J Clin Endocrinol Metab 1996;81:3535-3539.

5 Einaudi S, Lala R, Corrias A, Matarazzo P, Pagliardini S, de Sanctis C: Auxological and biochemical parameters in assessing treatment of infants and toddlers with congenital adrenal hyperplasia due to 21-hydroxylase deficiency. J Pediatr Endocrinol 1993;6:173178.

6 Claahsen-van der Grinten HL, Noordam K, Borm GF, Otten BJ: Absence of increased height velocity in the first year of life in untreated children with simple virilizing congenital adrenal hyperplasia. J Clin Endocrinol Metab 2006;91:1205-1209.

7 Prader A, Largo RH, Molinari L, Issler C: Physical growth of Swiss children from birth to 20 years of age. First Zurich longitudinal study of growth and development. Helv Paediatr Acta 1989;52:1-125.
8 Cole TJ, Freeman JV, Preece MA: Body mass index reference curves for the UK. Arch Dis Child 1995;73:25-29.

9 Greulich WW, Pyle SI: Radiographic Atlas of Skeletal Development of the Hand and Wrist, ed 2. Palo Alto, Stanford University Press, 1959

10 Joint LWPES/ESPE CAH Working Group: Consensus statement on 21-hydroxylase deficiency from the Lawson Wilkins Pediatric Endocrine Society and the European Society for Pediatric Endocrinology. J Clin Endocrinol Metab 2002;87:4048-4053.

11 Thilén A, Woods KA, Perry LA, Savage MO, Wedell A, Ritzén M: Early growth is not increased in untreated moderately severe 21-hydroxylase deficiency. Acta Paediatr 1995;84:894-898.

12 Balsamo A, Wasniewska M, Di Pasquale G, Salzano G, Baronio F, Bombaci S, De Luca F: Birth length and weight in congenital adrenal hyperplasia according to the different phenotypes. Eur J Pediatr 2006;165:380-383.

13 Jääskeläinen J, Voutilainen R: Growth of patients with 21-hydroxylase deficiency: an analysis of the factors influencing adult height. Pediatr Res 1997;41:30-33.

14 de Zegher F, Francois I, Boehmer ALM, Saggese G, Müller J, Hiort O, Sultan C, Clayton P, Brauner R, Cacciari E, Ibanez L, van Vliet G, Tiulpakov A, Saka N, Ritzen M, Sippell WG, Androgens and Fetal Growth Study Group: Androgens and fetal growth. Horm Res 1998;50:243-244.
15 Hofbauer LC, Khosla S: Androgen effects on bone metabolism: recent progress and controversies. Eur J Endocrinol 1999;140:271286

16 Hofbauer LC, Hicok KC, Khosla S: Effects of gonadal and adrenal androgens in a novel androgen-responsive human osteoblastic cell line. J Cellular Biochem 1998;71:96-108.

17 Gori F, Hofbauer LC, Conover CA, Khosla S Effects of androgens on the insulin-like growth factor system in an androgen-responsive human osteoblastic cell line. Endocrinol 1999;140:5579-5586.

18 Hargitai G, Solyom J, Battelino T, Lebl J, Pribilincova Z, Hauspie R, Kovacs J, Waldhauser F, Frisch H, MEWPE-CAH Study Group: Growth patterns and final height in congenital adrenal hyperplasia due to classical 21-hydroxylase deficiency. Horm Res 2001;55:161-171.

19 Manoli I, Kanaka-Gantenbein C, Voutetakis A, Maniati-Christidi M, Dacou-Voutetakis C: Early growth, pubertal development, body mass index and final height of patients with congenital adrenal hyperplasia: factors influencing the outcome. Clin Endocrinol 2002;57:669-676.

20 Stikkelbroeck NMML, vant Hof-Grootenboer BAE, Hermus ARMM, Otten BJ, vant Hof MA: Growth inhibition by glucocorticoid treatment in salt-wasting 21-hydroxylase deficiency: in early infancy and (pre)puberty. J Clin Endocrinol Metab 2003;88: 3525-3530. 